\title{
FÓRUM KISEBBSÉGKUTATÓ INTÉZET
}

Fórum Kisebbségkutató Intézet

Cím: Somorja, Park utca 4.

Honlap: http://foruminst.sk

E-mail: foruminst@foruminst.sk

Zalabai Zsigmond Városi Könyvtár

Cím: Somorja, Park utca 4.

Honlap: http://kniznicasamorin.sk

E-mail: kniznicasamorin@gmail.com

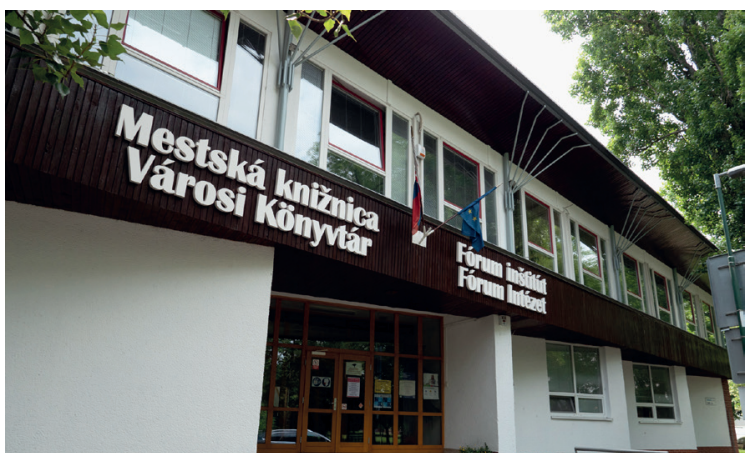

A Fórum Kisebbségkutató Intézet 1996-ban jött létre azzal a céllal, hogy megfelelő infrastrukturális és szakmai hátteret biztosítson a szlovákiai magyar társadalom különböző szegmenseinek tudományos igényü kutatásához. A nonprofit szervezetként múködő intézet székhelye Somorja, ahol az intézet székháza, tudományos könyvtára, levél- és kézirattára található. Itt múködik az intézet történeti, szociológiai és demográfiai, valamint nyelvi részlege, illetve az intézet digitalizációs központja is. Az intézet Etnológiai Központjának Komárom a székhelye.

A Fórum Kisebbségkutató Intézet szerves részét képezi a Bibliotheca Hungarica nevú tudományos könyvtár, amelynek elsődleges célja a szlovákiai magyar társadalom kutatásának elősegítése. A könyvtár gyűjtőkörét a volt Csehszlovákia, illetve a mai Szlovákia területén 1918-tól napjainkig megjelent magyar nyelvű, valamint a szlovákiai kisebbségek történelmére, művelődésére, társadalmi és politikai életére vonatkozó magyar és idegen nyelvű (szlovák, cseh, angol stb.) kiadványok alkotják. A könyvtár jelenleg mintegy 33 ezer feldolgozott kötettel rendelkezik.

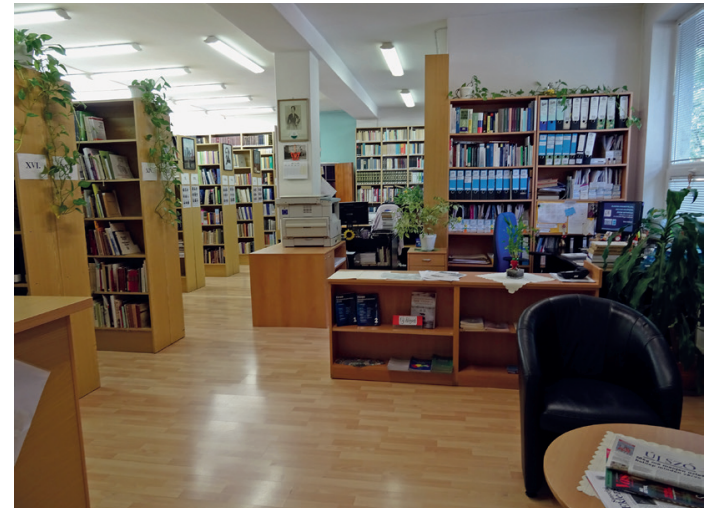


A Fórum Kisebbségkutató Intézet múködteti a vele egy épületben található Zalabai Zsigmond Városi Könyvtárat, amely Somorja város magyar és szlovák olvasóközönségét szolgálja ki. A könyvtárban mintegy 40 ezer kötet található, az olvasóteremben pedig 33 folyóiratból válogathatnak az olvasók.

A Fórum Kisebbségkutató Intézet belső munkatársainak száma 28, ebből a Bibliotheca Hungaricában és a Zalabai Zsigmond Városi Könyvtárban egyaránt 3-3 kolléga dolgozik.
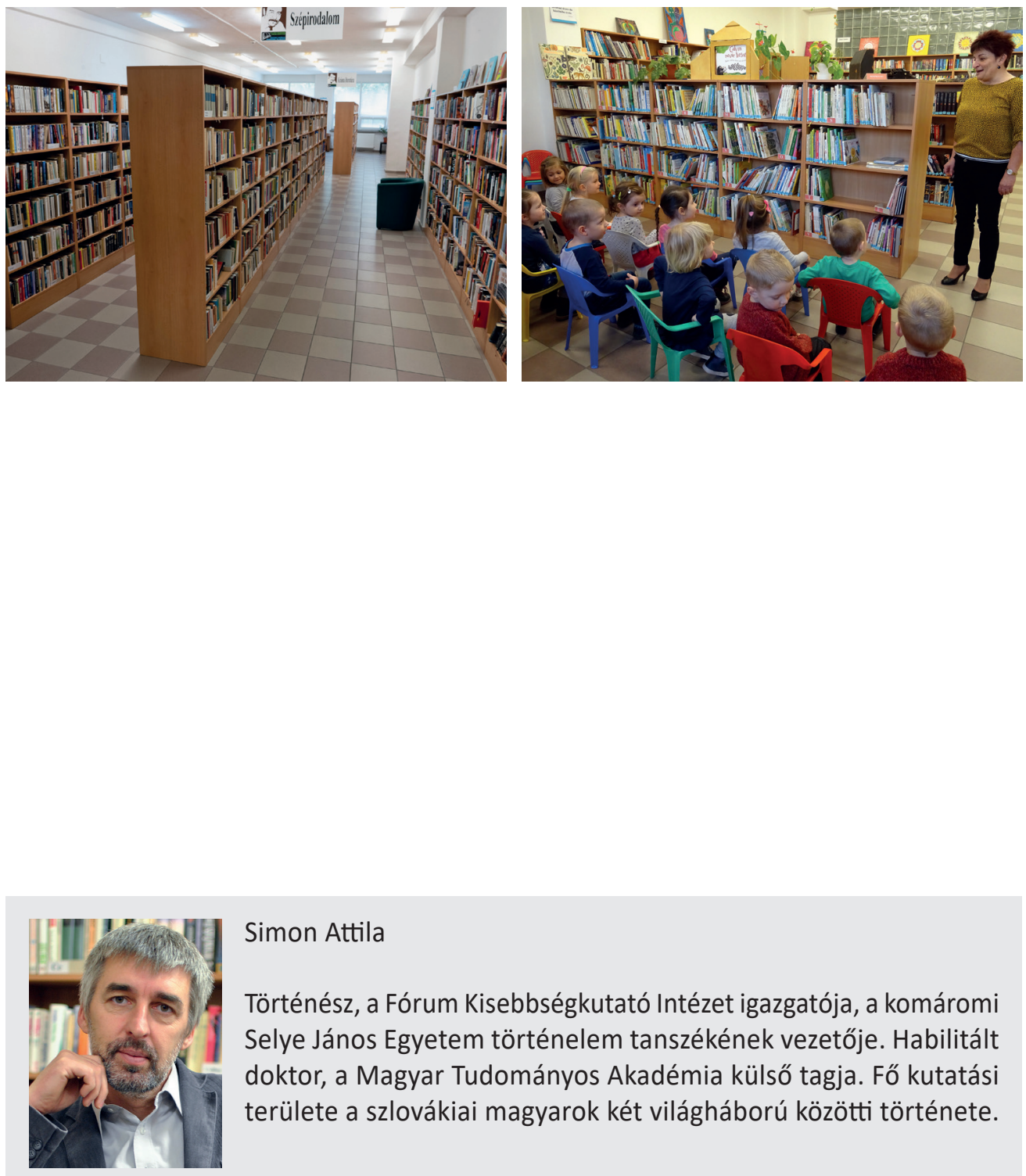

Simon Attila

Történész, a Fórum Kisebbségkutató Intézet igazgatója, a komáromi Selye János Egyetem történelem tanszékének vezetője. Habilitált doktor, a Magyar Tudományos Akadémia külső tagja. Fő kutatási területe a szlovákiai magyarok két világháború közötti története. 